\title{
A Case of Granulosa Cell Tumour with Atypical Presentation
}

\author{
S KABIR $^{\mathrm{a}}, \mathrm{AMAJUMDER}^{\mathrm{b}}, \mathrm{S}$ SHARMIN ${ }^{\mathrm{c}}$
}

\begin{abstract}
Summary:
Introduction: Granulosa cell tumour is one of the rare variations of ovarian tumour. As the Granulosa cells secrets Estradiol, the patient with granulosa cell tumour usually present with features of precautious puberty. But our patient present with androgenic features, which inspires us to report this atypical case.

Materials and methods: This young patient admitted in BBMH, as a diagnosed case of ovarian tumour with features of virilisation. Evaluation of patient with history taking,
\end{abstract}

\section{Introduction:}

Granulosa Cell tumour [GCT] is one of the rare varieties of sex cord stromal tumours. It contributes $5 \%$ of ovarian tumors $^{1}$. Mean age of presentation is 13 years. Most patients present with sexual precocity due to excessive estrogen production and rarely produce Androgen ${ }^{2}$. Our patient presented with these rare features of tumour. Granulosa cell tumour was first described by Scully in $1977^{3}$. In contrast to adult type juvenile one is more aggressive with high mitotic index.

\section{Case Report :}

Miss X, a 16-year-old unmarried girl of middle class family got admitted with the complaints of secondary amenorrhoea and abnormal facial hair growth for last 1 year. According to the patient, she had history of spontaneous menarche at the age of 12 years and of regular cycle. She developed amenorrhoea for last one year and feeling heaviness in lower abdomen for last 6

a. Dr. Shanjida Kabir, Assistant Professor, Dept of Obs and Gynae, USTC, Chittagong.

b. Dr. Afroza Mojumder, Associate Professor, Dept of Obs and Gynae, USTC, Chittagong

c. Dr. Shahanaj Sharmin, Associate Professor, Dept of Obs and Gynae, CMSOGH, Chittagong

Address of Correspondence: Dr. Shanjida Kabir, Assistant Professor, Department of obstetrics and gynaecology, USTC, Chittagong. Mobile: 01815070717, E-mail: dr.shanjida.kabir@gmail.com

Received: 31 Jan., 2018

Accepted: 19 May, 2019 clinical examination and investigations are done, and information is noted accordingly.

Conclusion: Features of virilisation are a nightmare for a lady of 16 years old. So during management of this patient proper counselling is very crucial and during surgery ovarian reserve should be maintained as far as possible considering her future quality of life and obstetric outcome.

Keywords: Granulosa cell tumour, virilization.

(J Bangladesh Coll Phys Surg 2019; 37: 202-204)

DOI: http://dx.doi.org/10.3329/jbcps.v37i4.43351

months. On general examination, she had average body built, height 5 feet 3 inches, weight $52 \mathrm{kgs}$, hirsutism with male pattern and excessive course hairs on upper arms and lower limbs. On mons pubis the hair distribution is of normal female pattern. Other features of virilisation were absent except mild regression of breast. On abdominal examination mild tenderness was present over lower abdomen. Vaginal inspection revealed clitoromegaly $[2.5 \mathrm{~cm}]$. On digital rectal examination, there was a lump 8x $8 \mathrm{~cm}$ size, mobile, non-tender, firm on posterior fornix. Ultrasono scan revealed a solido -cystic mass $10 \times 7 \mathrm{~cm}$ at left adnexal area with small pelvic collection. Enocrinological studies of serum FSH, LH, ACTH were normal except serum Testosterone level, which was raised [15.6nmol/1]. On laparotomy, small amount of peritoneal fluid was found, aspirated and sent for cytology. A mass $10 x 8 \mathrm{~cm}$, party cystic partly solid, well capsulated was identified in left adnexal area. Opposite ovary and tube were healthy. There were no peritoneal seedlings or palpable pelvic or para aortic lymph nodes. Left sided salpingo-oophorectomy was done. Histopathogy revealed Granulosa cell tumour. Cytology of peritoneal fluid failed to identify any malignant cell. For abnormal hair growth she was advised dermatological consultation. Following surgery from next cycle, she resumed menstruation. Serum testosterone level regressed to normal within two months. After one year follow up she is having regular menstruations and has not developed any unwanted symptom. 


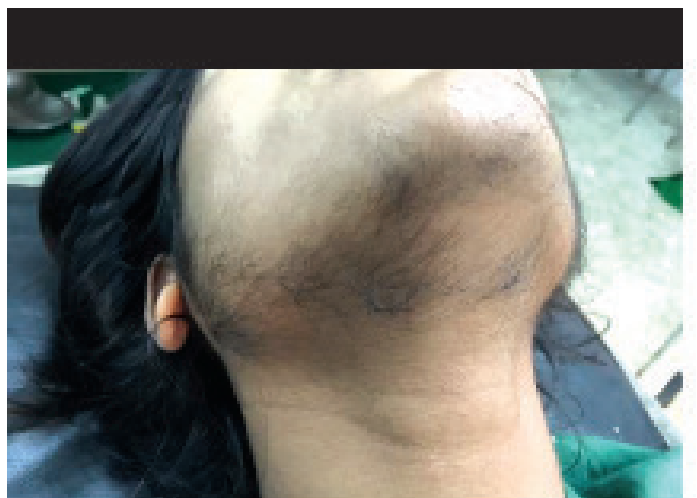

(a)

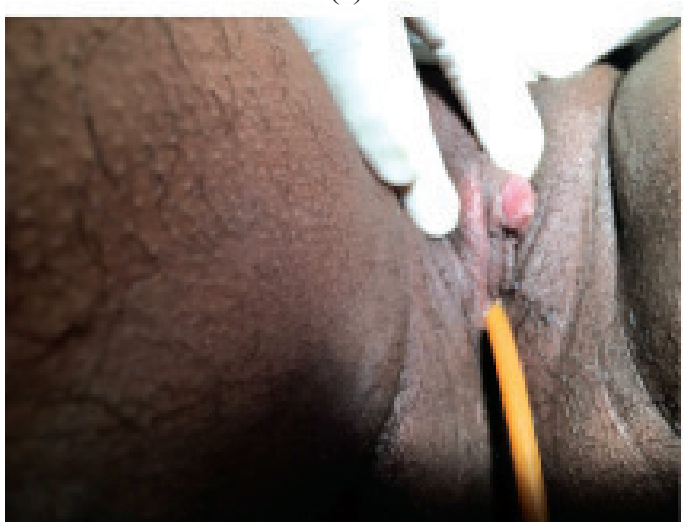

(c)

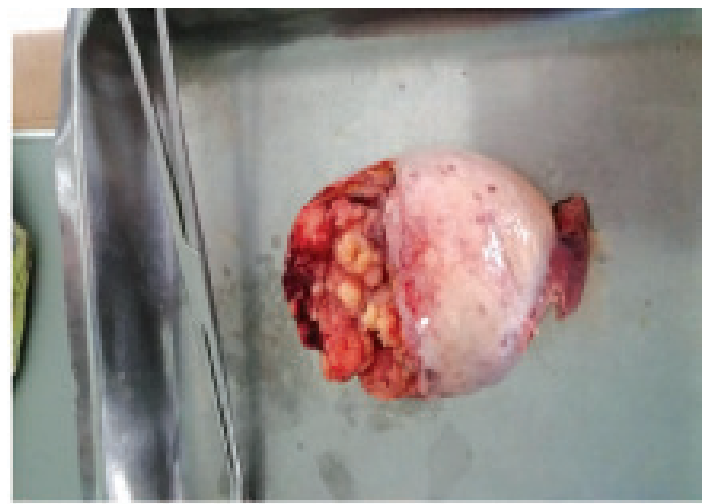

(b)

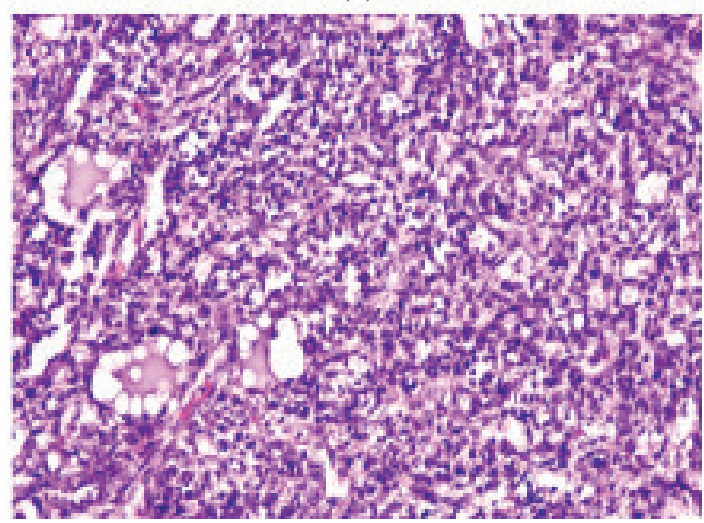

(d)

Fig.-1: a. Excessive facial hair growth, b. Clitoromegaly, c. Gross anatomy of tumour, d. Histopathological picture of tumour

\section{Discussion:}

Though ovarian tumours present late stage, hormonally active ovarian neoplasm like GCT are diagnosed early due to the effect of hormones on target tissues. This is a rare ovarian tumour with two distinct clinicopathological sub-type like Adult and Juvenile. Adult variety is common accounts to $95 \% .{ }^{[4]}$

Generally the adult variety occurs in peri [40-45years] and post menopausal women with peak incidence at $50-55$ years. The Juvenile one occurs in pre-pubertal age group. ${ }^{5}$ GCT as a hormone producing tumour [Estrogen] commonly present with sexual precaucity. Other presenting features are - pain abdomen, abdominal distension, menstrual abnormalities like- menorrhagia, inter-menstrual bleeding, post-menopausal bleeding. Endocrine manifestation are related with hyper-secretion of Estrogen from granulosa cells. ${ }^{6} 15 \%$ of the tumours are hormonally inert ${ }^{7}$.

One of the rare presentation of GCT is amenorrhoea with features of virilization. The luteinizing form produces androgen leading to virilisation. To date less than 50 cases of virilizing GCT have been reported in literature ${ }^{8}$. Our patient presented with this feature, the unique point which drew our attention to report the case.

Sunil kumarkota et al reported one case in which a 16year-old girl presented with primary amenorrhoea and virilization over 3years period. ${ }^{9}$ Another case report by Arunnayak at el in which a 19 years old unmarried girl presented with secondary amenorrhoea and virilizing features like our patient. ${ }^{10}$ She was stage $1 \mathrm{~A}$ and unilateral salpingo-oophorectomy was done. Another patient of 17 years, was reported by Reddy et al in the year 2014, presented with secondary amenorrhoea with pelvic mass ${ }^{[11}$. During reproductive age the typical picture of Androgen secretion is oligo-menorrhoea followed by amenorrhoea, defeminisation and progressive masculinization.

On physical examination, mass in lower abdomen could be palpable, usually unilateral upto $12 \mathrm{~cm}$. On cut section the tumour is multi loculated, cystic with yellow white solid area. On histo-pathological examination, there are five histological patterns like-micro, macro-follicular, insular, trabecular and spindle/sarcomatoid. Call Exner 
bodies are infrequently seen in GCT. ${ }^{12}$ Diffuse or multifollicular pattern with microcytes containing eosinophilic secretion and coffee bean nuclei are the commonest diagnostic point. In our case the gross and histology revealed these described features.

The serum tumour markers raised in GCT are Estradiol, Inhibin, Anti-mullerian hormone and CA- $125^{13}$. In our patient serum Testostereone level was elevated.

General management depends on stage of tumour and age of patient. Although there are no prospective, controlled and randomized studies, fertility sparing surgery is recommended because patients are commonly young adults and tumour is uni-lateral. Unilateral salpingo-oophorectomy is the treatment of choice. Total abdominal hysterectomy with bilateral salpingooophorectomy for patients who has completed family. As our patient was young unilateral salpingooophorectomy was done.

Ascitic fluid cytology positive for malignant cell were found in few cases in some studies. In our patient it was negative. As because LN- metastasis is rarely observed in patients with sex-cord stromal tumour, pelvic and paraaortic lymphadenectomy may not be included in the staging surgery of the patient. Ultimate diagnosis is done by histopathological examination. Due to Estrogen stimulation, there is chance of development of Endometrial carcinoma in $5-13 \%$ of cases ${ }^{14}$. Thus endometrial histopathology must be included in management protocol. The prognostic factors in GCT includes - staging, intra-peritoneal disease, tumour size, patient age, histologic grade of differentiation, mitotic activity and nuclear atypia ${ }^{[15]}$. Survival rate after 10 years for stage $1,2,3$ and 4 are $87 \%, 75 \%, 20 \%$ and $0 \%$ respectively. $^{7}$

The role of adjuvant therapy is controversial. But it is recommended in advanced stage disease. Limited data are available regarding the chemotherapeutic agents in stage 3 and 4 disease. BEP therapy have been tried successfully. Radiotherapy is reserved for recurrent disease in selected group of patients. As these tumours are known for relapse, long term follow-up is necessary for early detection.

\section{Conclusion:}

Our patient presented with some unusual characteristics of GCT. She did not present with precautious puberty, rather presented with secondary amenorrhoea. Abnormal hormonal secretion consisted mainly of Androgen, with sign of virilisation, which is a nightmare for any young adult female. But medical science is magic at some point; it removes all her agony by a simple incision and changes her life.

\section{Reference:}

1. Raafat MD, KlysH, Rylance G. Juvenile Granulosa cell tumour. Pediator Pathol.1990;10:617-23[Pub Med]

2. Scully KE. Ovarian tumors. Am J Pathol.1977;8:686720[PMC free article][Pub Med]

3. Larizza D, Calcaterra V, Sampaolo PLanati G, Brambilla P, Monciello T, Cesari S. Unusual presentation of juvenile Granulosa cell tumour of ovary. J Endocrinolinvest .2006 .july - aug ; 29 (7) ; 653-6.

4. Ukah CO, IK peze OC, Eleje GU, Eke AC. Adult granulosa cell tumour associated with endometrial carcinoma- A case report. J Med Case Rep.2011;5:340.[Pubmed]

5. Sivasankanansi, itam P, Ayensu- loker 2, Sanchez J, Egler RA, Anderson ML, et al. Juvenile Granulosa cell ovarian tumour.A case report and review of literature. J PediatrAdolesc Gynecol. 2009;22; e114 -e7 [pub med].

6. Takemori M, Nishimura R, Hasegawa, K. Ovarian thecoma with ascites and high serum level of CA-125.Anch Gynecol Obstet.2000;264:42-4.

7. Sekkat S, Kairouani M, Serji B, Tazi A, Mrabti H, Boutayeb $\mathrm{S}$, et al. Ovarian granulosa cell tumours: A retrospective study of 27 cases and a review of the literature. World J SuryOncol .2013;11:142.[pubmed]

8. Pautrier P, Chomme C, Culine S, Duvillard P, Michel G, Bidart J M et al.Adultgranulosa cell tumour of the ovary: A retrospective analysis study of 45 cases.Int J Gynecol Cancer.2003;7:58-65.[pubmed]

9. Sunil Kumar Kota, KotniGayatri, KirtikumarD.Modi. Ovarian granulosa cell tumour: An uncommon presentation with primary amenorrhoea and virilisation in a pubertal girl. Indian J Endocrinol Metab.2012Sept-Oct;16[5]:836839.

10. Nayak A, Sarmalker M, Mehendale M, Singh N, Shah S.A Rare case of Ovarian Granulosa cell tumour in Adolesent girl with secondary amenorrhoea and virilisation: A case report. Int J ReprodContraceptObstetGynecol 2015; 4: 1653-6.

11. Reddy K, Pavithra D, Ragini R, Pallivis. Juvenile granulosa cell tumour ; A rare clinical entity . Int J RepordContraceptObstet Gynecol. 2014;3:1150-54.

12. Zhang M, Cheung MK, Shin J Y, Kapp DS, HusainA, Teng $\mathrm{NN}$ et al . Prognostic factors responsible for survival in sex cord stromal tumour of ovary : An analysis of 376 women. GynecolOncol. 2007; 104 :396-400.[pubmed].

13. Koukourakis GV, Kouloulias VE, Koukourakis MJ, Zacharias GA, Papadimitriou C,Mystakidou K, et al. Granulosa cell tumour of the ovary: literature review. Integr Cancer Ther. 2008; 7:204-15.[pubmed].

14. Adhikari RC, Jha A, Shayami G. Granulosa cell tumour of ovary:Aclinico-pathologicalstudy of six cases. J Pathol Nepal. 2011;1:96-99.

15. Ellouze S, Krichen-Makni S, Trabelsik K, Ayadil, Sellami A, Khalibir A et al. Granulosa cell tumour of the ovary: Report of 16 cases. J Gynecol Obstet Biol Repod [Paris] 2006;35:767-72[pubmed]. 